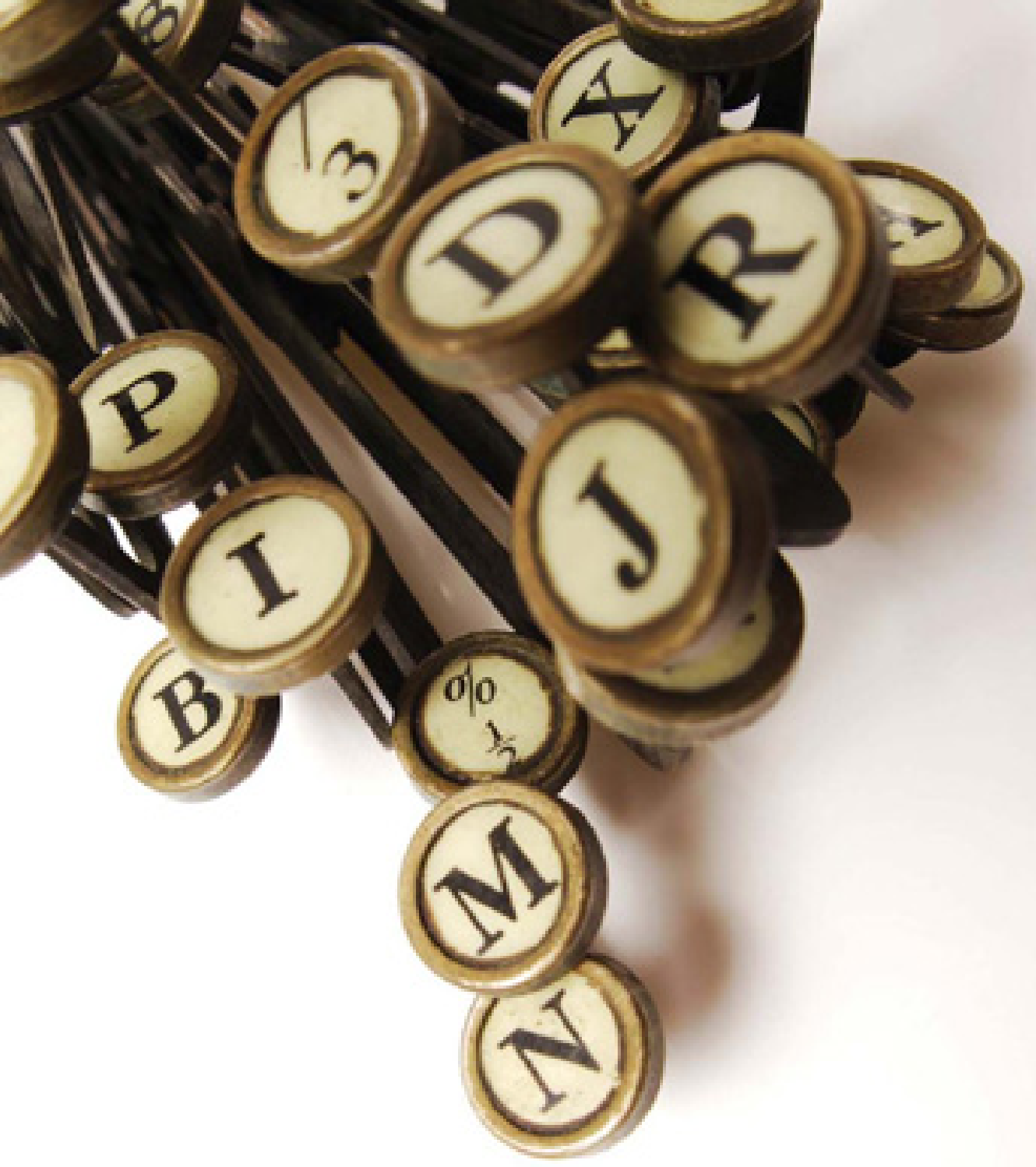




\section{A. S. Byatt}

\section{MANCHESTER 1824}

Manchester University Press 


\section{Contemporary British Novelists}

Series editor:

Daniel Lea

already published

J. G. Ballard Andrzej Gạsiorek

Pat Barker John Brannigan

Jim Crace Philip Tew

James Kelman Simon Kővesi

Iain Sinclair Brian Baker

Graham Swift Daniel Lea

Irvine Welsh Aaron Kelly

Jeanette Winterson Susana Onega 


\section{A. S. Byatt Critical Storytelling}

Alexa Alfer and Amy J. Edwards de Campos

Manchester University Press

Manchester 
Copyright (C) Alexa Alfer and Amy J. Edwards de Campos 2010

The right of Alexa Alfer and Amy J. Edwards de Campos to be identified as the authors of this work has been asserted by them in accordance with the Copyright, Designs and Patents Act 1988.

Published by Manchester University Press

Altrincham Street, Manchester Mi 7JA, UK

www.manchesteruniversitypress.co.uk

British Library Cataloguing-in-Publication Data

A catalogue record for this book is available from the British Library

Library of Congress Cataloging-in-Publication Data applied for

ISBN 978 ० 7190 66528 hardback

First published 2010

The publisher has no responsibility for the persistence or accuracy of URLs for any external or third-party internet websites referred to in this book, and does not guarantee that any content on such websites is, or will remain, accurate or appropriate.

Typeset

by Florence Production Ltd, Stoodleigh, Devon 